\title{
Fatty acid, tocopherol and squalene contents of Rosaceae seed oils
}

\author{
Bertrand Matthaus ${ }^{1}$ and Mehmet Musa Özcan ${ }^{2 *}$
}

\begin{abstract}
Background: The aim of current study is to establish the composition of these seeds belong to Rosaceae family with respect to fatty acid, tocopherol and squalene content.

Results: The oil contents of seeds varied between 3.49 (Cotoneaster bullatus) to $46.15 \mathrm{~g} / 100 \mathrm{~g}$ (Prunus tenella). The main fatty acids of seed oils were oleic (6.50 - 67.11\%), linoleic (22.08 - 68.62 \%) and 20:1n-7 (0.10 - 61.59\%). As observed, the oils of seed were rich in linoleic and oleic acids. Total tocopherol contents ranged between $7.06 \mathrm{mg} /$ $100 \mathrm{~g}$ (Prunus tenella) to $165.74 \mathrm{mg} / 100 \mathrm{~g}$ (Potentilla glandulosa ssp. pseudorupestris). The major tocopherols were Y-tocopherol, ranging from $2.08 \mathrm{mg} / 100 \mathrm{~g}$ to $106.01 \mathrm{mg} / 100 \mathrm{~g}$; a-tocopherol ranging from $2.86 \mathrm{mg} 100 \mathrm{~g}$ to 74.26 $\mathrm{mg} / 100 \mathrm{~g}$ and $\delta$-tocopherol ranging used in this experiment were found between $0.02 \mathrm{mg} / 100 \mathrm{~g}$ (Alchemilla caucasica) to $0.29 \mathrm{mg} / 100 \mathrm{~g}$ (Cotoneaster simonsii).
\end{abstract}

Conclusions: These results show that Rosaceae seed oils can be a potential saurce of valuable oil which might be useful for the evaluation of dietary information in important food crops and other industrial applications.

Keywords: Rosaceae; Oil content; Fatty acid; Tocopherol; Squalen

\section{Background}

Some seed oils are already used for several purposes: blending higly saturated edible oils to provide new oils with modified nutritional values, as ingredients in paint and varnish formulations, surface coating and oleochemicals and as oils for cosmetic purposes (Helmy 1990). Several species of Rosaceae presently have great commercial value as oil crops, e.g. Aronia melanocarpa L., Rosa canina, severeal and Rubus spp (Pourrat and Carnat 1981; Johansson et al. 1997; Xu et al. 2006; Oh et al. 2007). Plant seeds are important sources of oils of nutritional, industrial and pharmaceutical importance. No oil from any single source has been found to be suitable for all purposes because oils from different sources generally differ in their fatty acid composition. The fatty acid composition of the endogenous fats plays an important role in determining shelf life, nutrition and flavor of food products (Gao and Mazza 1995). The study of oil seeds for their minor constituents is useful in

\footnotetext{
* Correspondence: mozcan@selcuk.edu.tr

${ }^{2}$ Department of Food Engineering, Faculty of Agriculture, Selcuk Universty, 42031 Konya, Turkey

Full list of author information is available at the end of the article
}

order that both the oil and its minor constituents be used effectively (Ramadan and Mörsel 2002). Tocopherols and squalene are components present in the unsaponifiable lipid fraction of foods. $\alpha$ - Tocopherol, the most common form of vitamin $\mathrm{E}$ present in nature, is the most biologically active (Bjorneboe et al. 1990), and is preferentially retained in large quantities and transported to body components (Traber et al. 1990; Ching and Mohamed 2001). Konings et al. (1996)) developed a HPLC method for determination of tocopherols and tocotrienols in margarine, infant foods and vegetables. The main biochemical function of the tocopherols is believed to be the protection of polyunsaturated fatty acids aganist peroxidation (Beringer and Dompert 1976; Kamel-Eldin and Andersson 1997). They have vitamin E properties and display antioxidant activity, which protect the body tissues aganist the damaging effects caused by the free radicals that results from many normal metabolic functions (Lopez Ortiz et al. 2006). The major fatty acids composing the oils were linoleic (41-70\%), linolenic (13-36\%), and oleic (11-19\%) acids (Pourrat and Carnat 1981; Johansson et al. 1997; Oomah et al. 2000; Bushman et al. 2004). At the same time, tocopherols, the major vitamin of vitamin $\mathrm{E}$ are fat-soluble antioxidants 
that function as scavengers of lipid peroxyl radicals (Ryan et al. 2007).

Squalene, a 30 carbon isoprenoid, is a key intermediate in cholesterol biosynthesis and is abundant in shark liver oil and olive oil (Ryan et al. 2007). More recently, squalene has been shown to act as an antidote to reduce accidental drug-induced toxicities (Aguilera et al. 2005; Senthilkumar et al. 2006; Ryan et al. 2007). The protective effect of squalene may be attributed to its ability to serve as an antioxidant (Ryan et al. 2007). To achieve the most economical and efficient utilization of these seeds, more information on the varieties, properties and composition is required. Therefore, the present study attempted to establish the composition of these seeds belong to Rosaceae family with respect to fatty acid, tocopherol and squalene content.

\section{Methods \\ Seeds}

About 26 variety of plants belong to Rosaceae family were collected from plants growing in Botanical Garden of Germany (Alchemilla caucasica, Cotoneaster bullatus, Cotoneaster dielsianus, Cotoneaster francheti, Cotoneaster moupinensis, Cotoneaster simonsii, Dryas drummondii, Exochorda racemosa, Geum elatum, Geum magellanicum, Geum pyrenaicum, Potentilla alchimilloides, Potentilla ambigua, Potentilla argyrophylla var.leucochroa, Potentilla atrosanguinea, Potentilla aurea, Potentilla glandulosa, Potentilla grammopetala, Potentilla hippiana, Potentilla pyrenaica, Potentilla speciosa, Potentilla tridentate, Potentilla visianii, Prinsepia uniflora, Prunus tenella and Rosa palustris) in August, 2007 year. The seeds were cleaned in air screen cleaner to remove immature and broken seeds, dried by air condition. The seeds were stored in paper bags at $+4^{\circ} \mathrm{C}$ temperature.

\section{Reagents}

Petroleum ether $\left(40-60^{\circ} \mathrm{C}\right)$ was of analytical grade $(>98 \%$; Merck, Darmstadt, Germany). Heptane and tert-butyl methyl ether were of HPLC grade (Merck, Darmstadt, Germany). Tocopherol and tocotrienol standard compounds were purchased from CalBiochem (Darmstadt, Germany).

\section{Oil content}

The oil content was determined according to the method ISO 659:1998 (ISO,1998). About $2 \mathrm{~g}$ of the seeds were ground in a ball mill and extracted with petroleum ether in a Twisselmann apparatus for $6 \mathrm{~h}$. The solvent was removed by a rotary evaporator at $40^{\circ} \mathrm{C}$ and 25 Torr. The oil was dried by a stream of nitrogen and stored at $-20^{\circ} \mathrm{C}$ until used.

\section{Fatty acid composition}

The fatty acid composition was determined following the ISO standard ISO 5509:2000 (ISO 2000). In brief, one drop of the oil was dissolved in $1 \mathrm{~mL}$ of $n$-heptane, $50 \mu \mathrm{g}$ of sodium methylate was added, and the closed tube was agitated vigorously for $1 \mathrm{~min}$ at room temperature. After addition of $100 \mu \mathrm{L}$ of water, the tube was centrifuged at $4500 \mathrm{~g}$ for $10 \mathrm{~min}$ and the lower aqueous phase was removed. Then $50 \mu \mathrm{L}$ of $\mathrm{HCl}(1 \mathrm{~mol}$ with methyl orange) was added, the solution was shortly mixed, and the lower aqueous phase was rejected. About $20 \mathrm{mg}$ of sodium hydrogen sulphate (monohydrate, extra pure; Merck, Darmstadt, Germany) was added, and after centrifugation at $4500 \mathrm{~g}$ for $10 \mathrm{~min}$, the top n-heptane phase was transferred to a vial and injected in a Varian 5890 gas chromotograph with a capillary column, CP-Sil 88 (100 m long, $0.25 \mathrm{~mm}$ ID, film thickness $0.2 \mu \mathrm{m}$ ). The temperature program was as follows: from $155^{\circ} \mathrm{C}$; heated to $220^{\circ} \mathrm{C}\left(1.5^{\circ} \mathrm{C} / \mathrm{min}\right), 10 \mathrm{~min}$ isotherm; injector

\section{Table 1 Oil contents of some Rosaceae seeds}

\begin{tabular}{ll}
\hline Samples & Oil contents (\%) \\
\hline Alchemilla caucasica & 25.99 \\
Cotoneaster bullatus & 3.49 \\
Cotoneaster dielsianus & 7.56 \\
Cotoneaster francheti & 5.22 \\
Cotoneaster moupinensis & 5.29 \\
Cotoneaster simonsii & 3.91 \\
Dryas drummondii & 21.82 \\
Exochorda racemosa & 19.56 \\
Geum elatum & 17.38 \\
Geum magellanicum & 19.04 \\
Geum pyrenaicum & 14.53 \\
Potentilla alchimilloides & 20.23 \\
Potentilla ambigua & 9.71 \\
Potentilla argyrophylla var.leucochroa & 17.48 \\
Potentilla atrosanguinea & 23.81 \\
Potentilla aurea & 28.93 \\
Potentilla glandulosa & 28.95 \\
Potentilla grammopetala & 19.01 \\
Potentilla hippiana & 28.60 \\
Potentilla pyrenaica & 23.92 \\
Potentilla speciosa & 15.09 \\
Potentilla tridentate & 18.41 \\
Potentilla visianii & 23.80 \\
Prunus tenella uniflora & 41.82 \\
Rosa palustris & 46.15 \\
& 16.06 \\
\hline
\end{tabular}


$250^{\circ} \mathrm{C}$, detector $250^{\circ} \mathrm{C}$; carrier gas $36 \mathrm{~cm} / \mathrm{s}$ hydrogen; split ratio 1:50; detector gas $30 \mathrm{~mL} / \mathrm{min}$ hydrogen; $300 \mathrm{~mL} / \mathrm{min}$ air and $30 \mathrm{~mL} / \mathrm{min}$ nitrogen; manual injection volume less than $1 \mu \mathrm{L}$. The peak areas were computed by the integration software, and percentages of fatty acid methyl esters (FAME) were obtained as weight percent by direct internal normalization.

\section{Tocopherols}

For determination of tocopherols, a solution of $250 \mathrm{mg}$ of oil in $25 \mathrm{~mL}$ of $\mathrm{n}$-heptane was directly used for the HPLC. The HPLC analysis was conducted using a Merck-Hitachi low-pressure gradient system, fitted with a L-6000 pump, a Merck-Hitachi F-1000 fluorescence sp ectrophotometer (detector wavelengths for excitation $295 \mathrm{~nm}$, for emission $330 \mathrm{~nm}$ ), and a D-2500 integration system. The samples in the amount of $20 \mu \mathrm{L}$ were injected by a Merck 655 -A40 autosampler onto a Diol phase HPLC column $25 \mathrm{~cm} \times 4.6$ mmID (Merck, Darmstadt, Germany) used with a flow rate of $1.3 \mathrm{~mL} / \mathrm{min}$. The mobile phase used was n-heptane/tert-butyl methyl ether $(99+1$, v/v).

\section{Results and discussion}

Percentages of the lipidic fraction of the 26 plant seeds belong to Rosaceae familya re given in Table 1. Oil contents of samples changed between $3.49 \mathrm{~g} / 100 \mathrm{~g}$ and $46.15 \mathrm{~g} / 100 \mathrm{~g}$. On average terms, seeds contained 19.45\%. However, due to the economical value of oil content, they are both valuable as raw material for oil extraction. The authors found numerous references in the literature composition of the lipidic fraction for some Rosaceae seeds. Studies based on varieties give results that ranged between 9.0 and 23\% (Pourrat and Carnat 1981; Johansson et al. 1997; Zlatanov 1999; Oomah et al. 2000; Bushman et al. 2004; Oh et al. 2007).

The most abundant fatty acids in seed oils were oleic, linoleic and 20:1n-7 acids, accounting for 96.63 to $99.80 \%$ in seed oils. The oils extracted from Rosaceae

Table 2 Fatty acid compositions of Rosaceae seed oils (\%)

\begin{tabular}{|c|c|c|c|c|c|c|c|c|c|}
\hline \multirow[t]{2}{*}{ Samples } & \multicolumn{9}{|c|}{ Fatty acids } \\
\hline & Palmitic & Palmitoleic & Stearic & Oleic & Vaccenic & Linoleic & Linolenic & Eicosenoic & $20: 1 n-7$ \\
\hline Alchemilla caucasica & 4.15 & 0.07 & 1.96 & 10.54 & 0.31 & 31.29 & - & 0.24 & 50.29 \\
\hline Cotoneaster bullatus & 7.89 & 0.29 & 1.45 & 20.57 & 1.26 & 60.04 & 3.30 & - & 0.46 \\
\hline Cotoneaster dielsianus & 9.17 & 0.13 & 4.27 & 29.81 & 0.28 & 51.89 & 0.67 & - & 0.42 \\
\hline Cotoneaster francheti & 8.77 & 0.16 & 1.37 & 16.67 & 0.49 & 66.60 & 0.77 & - & 0.62 \\
\hline Cotoneaster moupinensis & 6.66 & 0.21 & 1.48 & 26.59 & 0.44 & 59.85 & 0.88 & - & 0.53 \\
\hline Cotoneaster simonsii & 6.81 & 0.25 & 1.19 & 19.52 & 0.49 & 64.64 & 1.47 & - & 0.94 \\
\hline Dryas drummondii & 5.92 & 0.30 & 1.73 & 22.72 & 0.40 & 56.82 & 0.05 & 1.31 & 6.20 \\
\hline Exochorda racemosa & 6.84 & 0.18 & 2.50 & 18.54 & 0.43 & 68.62 & 0.47 & - & 0.16 \\
\hline Geum elatum & 8.19 & 0.17 & 2.06 & 20.30 & 0.40 & 39.25 & 0.06 & 0.06 & 27.20 \\
\hline Geum magellanicum & 4.73 & 0.06 & 2.07 & 17.62 & 0.39 & 29.69 & 0.03 & 0.13 & 43.23 \\
\hline Geum pyrenaicum & 6.06 & 0.18 & 3.43 & 34.45 & 0.51 & 22.61 & 0.07 & 0.08 & 30.28 \\
\hline Potentilla alchimilloides & 6.09 & 0.09 & 2.44 & 7.89 & 0.40 & 26.74 & - & 0.16 & 55.02 \\
\hline Potentilla ambigua & 5.65 & 0.18 & 0.98 & 13.13 & 0.57 & 22.67 & 0.37 & 0.12 & 52.70 \\
\hline Potentilla argyrophylla & 4.46 & 0.15 & 1.44 & 6.50 & 0.41 & 28.04 & - & 0.63 & 57.25 \\
\hline Potentilla atrosanguinea & 4.20 & 0.13 & 1.44 & 11.31 & 0.43 & 32.84 & - & 0.14 & 48.59 \\
\hline Potentilla aurea & 5.16 & 0.13 & 1.59 & 10.91 & 0.35 & 26.17 & - & 0.84 & 53.78 \\
\hline Potentilla glandulosa & 4.37 & 0.22 & 1.22 & 13.41 & 0.51 & 25.91 & - & 0.82 & 52.20 \\
\hline Potentilla grammopetala & 5.32 & 0.09 & 2.00 & 9.77 & 0.36 & 27.89 & - & 0.52 & 52.91 \\
\hline Potentilla hippiana & 4.64 & 0.12 & 1.40 & 10.80 & 0.70 & 22.08 & 0.03 & 0.16 & 57.89 \\
\hline Potentilla pyrenaica & 4.93 & 0.08 & 1.99 & 12.90 & 0.29 & 29.65 & - & 0.86 & 48.28 \\
\hline Potentilla speciosa & 7.81 & 0.13 & 2.07 & 19.21 & 0.55 & 26.73 & - & 0.11 & 40.94 \\
\hline Potentilla tridentate & 4.30 & 0.13 & 1.88 & 14.13 & 0.39 & 40.85 & - & 0.60 & 36.53 \\
\hline Potentilla visianii & 3.25 & 0.05 & 1.55 & 8.14 & 0.33 & 23.27 & - & 0.70 & 61.59 \\
\hline Prinsepia uniflora & 5.20 & 0.17 & 1.75 & 28.22 & 0.41 & 60.92 & 0.34 & - & 0.44 \\
\hline Prunus tenella & 3.48 & 0.23 & - & 67.11 & - & 26.76 & 0.16 & - & 0.10 \\
\hline Rosa palustris & 5.04 & 0.19 & 1.74 & 15.77 & 0.56 & 27.56 & 0.15 & 0.83 & 45.37 \\
\hline
\end{tabular}


seeds were composed of 3.25-9.17\% palmitic, 1.19-4.27\% stearic, $6.50-67.11 \%$ oleic, $22.08-68.62 \%$ linoleic and $0.10-61.59 \%$ eicosenoic acids (Table 2). The proportion of linoleic acid in the seed oil of Exochorda racemosa was higher than that in the seed oil of Potentilla hippiana. This proportion was also higher than those of in other some seed oils (Pourrat and Carnat 1981; Bushman et al. 2004; Matthaus and Ozcan 2005; Oh et al. 2007). The erucic acid species of this genus contain from the linolenic acid (Table 2). As can be observed, the oils of all seed oils used in this experiment had higher linoleic acid content than those of other fatty acids. On the other hand, oleic acid contents of seed oils varied between $6.5 \%$ (Potentilla argyrophylla var. leucochroa) to $67.11 \%$ (Prunus tenella).

Nutritionally unfavorable is the high content of saturated fatty acids, consisting of palmitic acid, which amounted to between $3.25 \%$ (Potentilla visianii) to $9.17 \%$ (Cotoneaster dielsianus), and stearic acid, which was found in a very small range between 1.19\% (Cotoneaster simonsii) to $4.27 \%$ (Cotoneaster dielsianus). However, Rosaceae seed oil used in this experiment contain more linoleic and 20:1 n-7 (except for a few seed oils) acids and less stearic and palmitic acids. Also, the oils of some seed, contained a high propertion of 20:1 n-7. The main fatty acids in bramble seed oils are C18:2n -6 (51.0-66.1\%), C18:3n-3 (9.70-35.6\%), C18:1n-9 (9.85-16.3) and C16:0 (2.01-5.73\%) (Xu et al. 2006). In general, high amounts of linoleic acid are unsuitable for oil-food products due to its instability and reversion of flavor associated with autoxidation (Green 1986; Singh et al. 1998). So, these seed oils may be a suitable oil seed crop for the various industry due to its very low content of linolenic and high content of linoleic acid (Singh et al. 1998). Those observations are in agreement with the data reported earlier about the fatty acid composition of some seed oils (Tiscornia et al. 1976; Zlatanov et al. 1997; Zlatanov 1999).

Most plants deriveted foods contain low to moderate levels of vitamin E activity. However, oving to the abundance of plant-derived foods in our diets, they provide a

Table 3 Tocopherol contents of some Rosaceae seed oils (mg/100 g)

\begin{tabular}{|c|c|c|c|c|c|c|c|c|c|c|}
\hline & $a$ & a-T3 & $\beta-T$ & Y-T & $\beta-$-T3 & P8 & $\mathrm{Y}$-T3 & $\Delta-\mathrm{T}$ & $\Delta-\mathrm{T3}$ & Sum \\
\hline Alchemilla caucasica & 6.17 & 5.64 & 0.00 & 15.90 & 0.00 & 0.00 & 0.00 & 0.60 & 0.00 & 28.31 \\
\hline Cotoneaster bullatus & 53.56 & 56.84 & 0.00 & 285.49 & 0.00 & 0.00 & 0.00 & 0.00 & 0.00 & 138.88 \\
\hline Cotoneaster dielsianus & 21.87 & 21.29 & 0,00 & 11,77 & 0,00 & 0,00 & 0,00 & 0,68 & 0,00 & 55,61 \\
\hline Cotoneaster francheti & 34.10 & 29.11 & 1,72 & 28,38 & 0,00 & 0,00 & 0,00 & 3,97 & 0,00 & 97,27 \\
\hline Cotoneaster moupinensis & 27.33 & 0.00 & 7,14 & 0,00 & 0,00 & 0,00 & 0,00 & 0,00 & 0,00 & 34,47 \\
\hline Cotoneaster simonsii & 74.26 & 0,00 & 74,72 & 2,08 & 0,00 & 5,10 & 0,00 & 1,57 & 0,00 & 157,73 \\
\hline Dryas drummondii & 10.47 & 0,00 & 0,37 & 13,68 & 0,00 & 0,42 & 0,00 & 0,69 & 0,00 & 25,63 \\
\hline Exochorda racemosa & 25,48 & 0,00 & 0,00 & 87,09 & 0,00 & 0,00 & 0,00 & 4,21 & 0,00 & 116,78 \\
\hline Geum elatum & 42,92 & 10,03 & 3,43 & 12,40 & 0,00 & 0,22 & 0,19 & 1,70 & 0,00 & 70,89 \\
\hline Geum magellanicum & 23,16 & 7,75 & 2,71 & 41,94 & 0,00 & 0,65 & 0,51 & 5,21 & 0,00 & 81,93 \\
\hline Geum pyrenaicum & 32,86 & 11,81 & 0,82 & 24,59 & 0,00 & 0,54 & 0,37 & 0,99 & 0,00 & 71,97 \\
\hline Potentilla alchimilloides & 11,67 & 10,17 & 0,50 & 27,48 & 0,00 & 0,36 & 0,39 & 4,98 & 0,00 & 55,55 \\
\hline Potentilla ambigua & 20,43 & 17,02 & 0,41 & 58,10 & 0,00 & 0,00 & 0,00 & 2,69 & 0,00 & 98,64 \\
\hline Potentilla argyrophylla & 12,51 & 10,14 & 1,21 & 48,55 & 0,00 & 0,23 & 0,27 & 44,56 & 0,00 & 117,45 \\
\hline Potentilla atrosanguinea & 9,88 & 7,75 & 99,00 & 37,11 & 0,00 & 0,95 & 0,47 & 25,33 & 0,00 & 82,48 \\
\hline Potentilla aurea & 7,58 & 5,54 & 1,54 & 39,38 & 0,00 & 0,29 & 0,38 & 73,59 & 0,00 & 128,30 \\
\hline Potentilla glandulasa & 5,89 & 0,00 & 0,28 & 106,01 & 0,00 & 0,46 & 0,16 & 52,94 & 0,00 & 165,74 \\
\hline Potentilla grammopetala & 8,06 & 0,00 & 0,41 & 33,42 & 0,00 & 0,29 & 0,47 & 3,96 & 0,00 & 46,61 \\
\hline Potentilla hippiana & 5,76 & 0,00 & 0,00 & 58,16 & 0,00 & 0,45 & 0,24 & 41,28 & 0,00 & 105,89 \\
\hline Potentilla pyrenaica & 10,13 & 8,05 & 1,41 & 15,04 & 0,00 & 0,30 & 0,25 & 68,30 & 0,53 & 104,01 \\
\hline Potentilla speciosa & 22,75 & 13,34 & 0,49 & 50,77 & 0,00 & 0,00 & 0,51 & 2,85 & 0,00 & 90,71 \\
\hline Potentilla tridentata & 10,96 & 9,97 & 0,18 & 21,83 & 0,00 & 0,42 & 0,44 & 0,83 & 0,00 & 44,63 \\
\hline Potentilla visianii & 9,17 & 7,50 & 0,39 & 55,99 & 0,00 & 0,31 & 0,25 & 9,28 & 0,00 & 82,89 \\
\hline Prinsepia uniflora & 6,11 & 0,00 & 0,00 & 39,79 & 0,00 & 0,00 & 0,29 & 2,85 & 0,00 & 49,04 \\
\hline Prunus tenella & 2,86 & 0,00 & 0,16 & 2,57 & 0,00 & 0,00 & 0,70 & 0,78 & 0,00 & 7.06 \\
\hline Rosa palustris & 11.55 & 0.00 & 0.60 & 43.05 & 0.00 & 0.59 & 0.26 & 1.90 & 0.72 & 58.67 \\
\hline
\end{tabular}


significant and consistent source of vitamin E (Eitenmiller and Lee 2004; Ryan et al. 2007). The tocopherol contents of seed oils researched in present study are listed in Table 3. All the seeds analysed exhibited differences in their tocopherol contents and the differences were found. The major tocopherol was $\gamma$-tocopherol in all the varieties of Rosaceae seed oils, which was higher in Potentilla glandulosa (106.01 mg/100 g) than in Cotoneaster simonnsii $(2.08 \mathrm{mg} / 100 \mathrm{~g})$. The contents of $\alpha$-tocopherol in seed oil of Cotoneaster simonsii (74.26 mg/100 g) were about 26x that of Prunus tenella (2.86 mg/100 g), and the content of tocopherol in Potentilla aurea seed oil (73.59 mg/100 g) was also hipher than that in Alchemilla caucasica (0.60 mg/100 g) oil. The total tocopherol in Potentilla glandulosa seed oil (165.74 $\mathrm{mg} / 100 \mathrm{~g})$ was higher than that in Prunus tenella $(7.06 \mathrm{mg} / 100 \mathrm{~g})$. Our results are higher than those of other authors ( $\alpha$-tocopherol and $\beta+$ $\gamma$-tocopherol) (Ryan et al. 2007). The major tocopherol in all bramble seed oils of 10 varieties was $\gamma$-tocopherol. The composition (mg/100 g) was as follows: $\alpha$-tocopherol 7.65-52.6, $\gamma$-tocopherol 46.9-106, $\delta$-tocopherol 3.1-9.50, and the active vitamin E 15.9-61.5 among the varieties (Xu et al. 2006). In the tocopherol fraction $(55.5 \mathrm{mg} / \mathrm{kg}$ in chokeberry oil, $249.6 \mathrm{mg} / \mathrm{kg}$ in black currant oil and $89.4 \mathrm{mg} / \mathrm{kg}$ in rose hip oil), $\alpha$-tocopherol predominated in chokeberry oil $(70.6 \mathrm{mg} / \mathrm{kg}) \cdot \gamma$-Tocopherol was the main component in black currant oil $(55.4 \mathrm{mg} / \mathrm{kg})$ and rose hip oil (71.0 mg/kg) (Zlatanov 1999). The content of tocopherols is $360 \mathrm{mg} / 100 \mathrm{~g}$ in the hexane extract oil of raspberry seed and the main component is the isomer (Oomah et al. 2000). In cold- pressed raspberry seed oil, the total tocopherols are $88.9 \mathrm{mg} / 100 \mathrm{~g}$ (Parry et al. 2005). So, because of the nutritional and antioxidant properties of tocopherols, Rosaceae seed oils should be taken into account. As a healthy product, the fatty acids and tocopherols in the seed oil are the major components (Oomah et al. 2000).

Squalene was determined in some Rosaceae seed oils employed in the present study; levels of squalene were found between $0.02 \mathrm{mg} / 100 \mathrm{~g}$ (Alchemilla caucasica) and $0.29 \mathrm{mg} / 100 \mathrm{~g}$ (Cotoneaster simonsii) (Table 4). Squalene, a biosynthetic precurson to all steroids both in plant and animal cells, also exists with phytosterols and tocopherols in the unsaponifiable fraction of foods. There is an obvious scarcity of data on squalene content in foods (Ryan et al. 2007).

In the tocopherol fraction $(55.5 \mathrm{mg} / \mathrm{kg}$ in chokeberry oil, $249.6 \mathrm{mg} / \mathrm{kg}$ in black currant oil and $89.4 \mathrm{mg} / \mathrm{kg}$ in rose hip oil), $\alpha$-tocopherol predominated in chokeberry oil $(70.6 \mathrm{mg} / \mathrm{kg})$. $\Gamma$-tocopherol was the main component in black currant oil $(55,4 \mathrm{mg} / \mathrm{kg})$ and rose hip oil (71.0 mg/kg) (Zlatanov 1999).

Among plant foods, amaranth, a pseudo cereal grain, contains relatively high amounts of squalene, approximately
Table 4 Squalene contents of some Rosaceae seeds

\begin{tabular}{ll}
\hline Samples & Concentrations (\%) \\
\hline Alchemilla caucasica & 0.02 \\
Cotoneaster bullatus & 0.22 \\
Cotoneaster dielsianus & 0.07 \\
Cotoneaster francheti & 0.13 \\
Cotoneaster moupinensis & 0.16 \\
Cotoneaster simonsii & 0.29 \\
Dryas drummondii & 0.09 \\
Exochorda racemosa & 0.14 \\
Geum elatum & 0.09 \\
Geum magellanicum & 0.05 \\
Geum pyrenaicum & 0.13 \\
Potentilla alchimilloides & 0.05 \\
Potentilla ambigua & 0.12 \\
Potentilla argyrophylla var.leucochroa & 0.05 \\
Potentilla atrosanguinea & 0.04 \\
Potentilla aurea & 0.04 \\
Potentilla glandulosa & 0.05 \\
Potentilla grammopetala & 0.07 \\
Potentilla hippiana & 0.03 \\
Potentilla pyrenaica & 0.05 \\
Potentilla speciosa & 0.07 \\
Potentilla tridentate & 0.05 \\
Prinsepia uniflora & 0.06 \\
\hline
\end{tabular}

$132 \mathrm{mg} / 100 \mathrm{~g}$ to $424 \mathrm{mg} / 100 \mathrm{~g}$ (Berganza et al. 2003). Another exceptionally rich source of squalene is olive oil, which is reported to contain 2000 to $7000 \mu \mathrm{g} / \mathrm{g}$ oil (Liu et al. 1976). In another study, Ryan et al. (2007)) identified 58.4 and $89.0 \mathrm{mg} / 100 \mathrm{~g}$ squalene in quinoa and pumpkin seed, respectively. The contents of other samples ranged between 0.2 barley to $8.8 \mathrm{mg} / 100$ (Millet). As a result, the squalene content of Rosaceae seed oils employed in the present study is lower than that of the squalene content reported for poppy, mustard pumpkin, sesame, millet, quinoa, spelt, lentils, peas and especially olive (Liu et al. 1976; Ryan et al. 2007). In addition, several experimental studies demonstrated the detoxifying activities of squalene against a wide range of chemicals such as arsenic, hexacholorobengene and Phenobarbital (Kamimara et al. 1992; Fan et al. 1996; Ryan et al. 2007).

\section{Conclusion}

The oil contents of seeds varied between 3.49 (Cotoneaster bullatus) to $46.15 \mathrm{~g} / 100 \mathrm{~g}$ (Prunus tenella). The main 
fatty acids in seed oils were oleic (6.50-67.11\%) and linoleic (22.08-68.62\%). The concentrations of total tocopherol ranged between $7.06 \mathrm{mg} / 100 \mathrm{~g}$ (Prunus tenella) to $165.74 \mathrm{mg} / 100 \mathrm{~g}$ (Potentilla glandulosa ssp. pseudorupestris). Squalene was determined in some Rosaceae seed oils employed in the present study; levels of squalene were notably low between $0.02 \mathrm{mg} / 100$ (Alchemilla caucasica) to $0.29 \mathrm{mg} / 100 \mathrm{~g}$ (Cotoneaster simonsii). The present study indicates that some Rosaceae seeds are good natural sources of oil. In addition, fatty acids, tocopherol and squalene in particular seem to have a very important effect on health.

\section{Competing interests}

The authors declare that they have no competing interests.

\section{Authors' contributions}

Both authors read and approved the final manuscript.

\section{Acknowledgements}

This work was supported by The Scientific and Technical Research of Turkey (TÜBITAK) and Deutsche Forschungs Gemeinschaft (DFG, Almanya). We are grateful to Dr J. Fiebig (Head of Institue). The authors also thank to Mrs E. Claudia, Miss E. Uda and Miss B. Bielefeld for skilful technical assistance with the GLC and HPLC.

\section{Author details}

'Institute fur for Lipid Research, Federal Research Center for Nutrition and Food, Piusallee 76, 48165 Munster, Germany. ${ }^{2}$ Department of Food Engineering, Faculty of Agriculture, Selcuk Universty, 42031 Konya, Turkey.

Received: 11 March 2014 Accepted: 10 May 2014

Published: 5 June 2014

\section{References}

Aguilera Y, Dorado ME, Prada FA, Martinez JJ, Quesada A, Ruiz-Gutierrez V (2005) The protective role of squalene in alcohol damage in the chick embryo retina. Experim Eye Res 80:535-543

Berganza BE, Moran AW, Rodriguez G, Coto NM, Santamaria M, Bressani R (2003) Effect of variety and location on the total fat, fatty acids and squalene content of Amaranth. Plant Food Hum Nutr 58:1-6

Beringer H, Dompert BWU (1976) Fatty acid and tocopherol pattern in oil seeds. Fette Seifen Anst 78(6):228-231

Bjorneboe A, Bjorneboe G, Drevon C (1990) Absorption, Transport and distribution of vitamin E. J Nutr 120:233-242

Bushman BS, Phillips B, Isbell T, Ou B, Crane JM, Knapp SJ (2004) Chemical composition of caneberry (Rubus spp.) seeds and oils and their antioxidant potential. J Agric Food Chem 52:7982-7987

Ching LS, Mohamed S (2001) Alpha-Tocopherol content in 62 edible tropical plants. J Agric Food Chem 49:3101-3105

Eitenmiller RR, Lee J (2004) Vitamin E: Food chemistry, composition and analysis. Marcel Dekker, New York

Fan S, Ho I, Yeoh FL, Lin C, Lee T (1996) Squalene inhibits sodium arseniteinduced sister chromatid exchanges and micronuclei in Chinese hamster ovary-Kl cells. Mutat Res 368:165-169

Gao L, Mazza G (1995) Characterization, quantitation, and distribution of anthocyanins and colorless phenolics in sweet cherries. J Agric Food Chem 43:343-346

Green AG (1986) Genetic control of polyunsaturated fatty acid biosynthesis in flax (Linum usitatissimum) seed oil. Theor Appl Gen 72:654-666

Helmy HE (1990) Studies on the pigments of some citrus, prune and cucurbit seed oils when processed with or without cottonseed oil. J Am Oil Chem Soc 67:376-380

Johansson AK, Kuusisto PH, Lakkso PH, Derome KK, Sepponen PJ, Katajisto JK (1997) Geographical variations in seed from Rubus chamaemorus and Empetrum nigrum. Phytochem 44(8):1421-1427
Kamel-Eldin A, Andersson RA (1997) A multivariate study of the correlation between tocopherol content and fatty acid compostion in vegetable oils. J Am Oil Chem Soc 74:375-380

Kamimara H, Koga N, Oguri K, Yoshimura H (1992) Enhanced elimination of theophylline, phenobarbital and strychnine from the bodies of rats and mice by squalene treatment. J Pharm 15:215-221

Konings EJM, Romans HHS, Beljaars PR (1996) Liquid chromotographic determination of tocopherols and tocotrienols in margarine, infant foods, and vegetables. J AOAC Int 79(4):902-906

Liu GCK, Ahjrens EH, Schreibman PH, Crouse JR (1976) Measurement of squalene in human tissues and plasma: validation and application. J Lipid Res 17:38-45

Lopez Ortiz CM, Prats Moya MS, Berenguer Navarro V (2006) A rapid chromatographic method for simultaneous determination of $\beta$-sitositerol and tocopherol homologues in vegetable oils. J Food Comp Analyses 19:141-149

Matthaus B, Özcan M (2005) Glucosinolates and fatty acid, sterol and tocopherol composition of seed oils from Capparis spinosa var. spinosa and Capparis ovata Desf. vr. canescens (Coss.) Heawood. J Agric Food Chem 53:7136-7141

Oh HH, Hwanng KT, Shin MK (2007) Oils in the seeds of Caneberries produced in Korea. J Am Oil Chem Soc 84:549-555

Oomah BD, Ladet S, David VG, Liang J, Girard B (2000) Characteristics of raspberry (Rubus idaeus L) seed oil. Food Chem 69:187-193

Parry J, Su L, Luther M, Zhou K, Yurawecz MP, Whittaker P (2005) Fatty acid composition and antioxidant properties of cold-pressed marionberry, red raspberry, and blueberry seed oils. J Agric Food Chem 53:566-573

Pourrat H, Carnat AP (1981) Chemical composition of raspberry seed oil (Rubus idaeus L. Rosaceae). Rev. Franh Crops and Grass 28:477-479

Ramadan MF, Mörsel JT (2002) Neutral lipid classes of black cumin (Nigella sativa L.) seed oils. Eur Food ResTechnol 214:202-206

Ryan E, Galvin K, O'Connor TP, Maguire AR (2007) Phytosterol, squalene, tocopheral content and fatty acid profile of selected seeds, grains, and legumes. Plants Food Human Nutr 62:85-91

Senthilkumar S, Devaki T, Manohar BM, Babu MS (2006) Effect of squalene on cyclophosphamide-induced toxicity. Clinica Chim Acta 364:335-342

Singh SP, Shukla S, Khanna KR, Dixit BS, Banerji R (1998) Variation of major fatty acids in F8 generation of Opium poppy (Papaver somniferum x Papaver setigerum) genotypes. J Sci Food Agric 76:168-172

Tiscornia E, Camurat F, Gastaldo P, Pagano M (1976) La frazione sterolica dele olio di pomodoro. Riv Italaly Sost Grasse 53:119-129

Traber MG, Burton GV, Ingold KU, Kayden HJ (1990) RRR- and SRR- alphatocopherols are secreted without discrimination in human cylomicrons, but RRR-alpha-tocopherol is preferentially secreted in very low-density lipoproteins. J Lipid Res 31:675-685

Xu Y, Zhang Y, Chen M, Tu P (2006) Fatty acids, tocopherols and proanthocyanidins in bramble seeds. Food Chem 99:586-590

Zlatanov MD (1999) Lipid composition of Bulgarian chokeberry, black currant and rose hip seed oils. J Sci Food Agric 79:1620-1624

Zlatanov M, Ivanov S, Antova G, Kouleva L (1997) Study of phospholipids composition of Rosaceae seed oils. Riv Ital Sost Grasse LXXIV(settebre):409-410

\section{doi:10.1186/s40529-014-0048-4}

Cite this article as: Matthaus and Özcan: Fatty acid, tocopherol and squalene contents of Rosaceae seed oils. Botanical Studies 2014 55:48.

\section{Submit your manuscript to a SpringerOpen ${ }^{\odot}$ journal and benefit from:}

- Convenient online submission

- Rigorous peer review

- Immediate publication on acceptance

- Open access: articles freely available online

- High visibility within the field

- Retaining the copyright to your article

Submit your next manuscript at $>$ springeropen.com 